Julita FIEDORCZUK, MA

Wydział Ekonomii i Zarządzania, Uniwersytet w Białymstoku

e-mail: fiedorczukjulita@uwb.edu.pl

Grażyna MICHALCZUK Ph.D., Professor of the University of Białystok Wydział Ekonomii i Zarządzania, Uniwersytet w Białymstoku

e-mail: g.michalczuk@uwb.edu.pl

DOI: $10.15290 /$ ose.2016.05.83.02

\title{
SIGNIFICANCE OF SKANDIA ACHIEVEMENTS IN THE DEVELOPMENT OF APPROACHES TO CONCEPTUALIZATION AND ASSESSMENT MODELS OF NATIONAL INTELLECTUAL CAPITAL
}

\begin{abstract}
Summary
A noteworthy group among the national intellectual capital conceptual approaches, allowing to an assessment of the NIC level, are methods based on a model developed by L. Edvinsson within Skandia company. The model is called "Skandia Navigator" and is the one of world's first proposal of the comprehensive measuring tool to enable for an evaluation and management of the intellectual capital.

The aim of the article is presentation of the significance of Skandia's and L. Edvinsson's achievements in development of the national intellectual capital concept. In this research paper selected conceptual models NIC are analysed, which to some extent relied on Skandia's model. The analysis was conducted paying special attention to the methodological apparatus structure and operationalization. The article is an effect of analysis main foreign literature and also aims at filling of the gap, which exists in publications about the NIC concept.

As a result of the considerations set out in this article, the following conclusions can be drawn. Skandia Navigator became an universal construction, irrespective of the size and type of the object of analysis. Edvinsson's model is constantly used as the foundation of assessment instrument in significant amount of scientific studies and reports for intellectual capital researches at the macroeconomic level. Original structure and assumptions of the method are slightly modified, but the changes depth never transform strongly Skandia prototype. This group of methods are easy to adapt and modify, what allow to adjust of the conceptualzation and methodology to the author's intentions and specific object of analysis. On the other hand, the ease of adaptation to identified conditions and applications may disclose the imperfections of the Skandia's methods. Analyzed conceptual models consists of four components in this research paper. In each of them appeared human capital. The development capital was the second, next to market and process capital, most common distincted element in NIC models. L. Edvinson's solutions (Skandia Navigator and Skandia Value Sheme) have been the pillars of many attempts of NIC assessment.
\end{abstract}

Key words: national intellectual capital (NIC), Skandia Navigator, Skandia Value Scheme, conceptualization of NIC, assessment NIC models.

JEL: 0110, 0340 


\section{Introduction}

A number of proposals for the conceptualization of intellectual capital and methods of its measurement and reporting have appeared over the last few years. In most cases, new models of intellectual capital are the modification the existing "classics" [Michalczuk, 2013, pp. 87, 91] The crucial achievement, systemizing knowledge of intellectual capital was Skandia's invention of new way of reporting "the hidden value" of the organization developed by Edvinsson.

Edvinsson initially distinguished two elements of intellectual capital: human and structural, which later was divided into relations and organizational capital. The threelevel structure of Edvinson's intellectual capital model permanently became part of the intellectual capital theory [Roslender, Fincham, 2004, p. 182]. Edvinsson's measuring tool has not become outdated, in spite of the changeability of conditions, the relevant progress in civilization and development, which occured in the mid 90s.

The pioneering Edvinsson's publications initiate the new approach for the evaluation of the intellectual capital with the macroeconomic prospect. Skandia Navigator became a hard core of the structure of the following NIC models and the base of the coming into existence of alternative approaches/models ${ }^{1}$ letting the diagnosis of the intellectual capital on a national scale.

The purpose of the article is presentation of the significance of Skandia's and L. Edvinsson's achievements in development of the national intellectual capital concept. In this research paper are analysed selected conceptual models NIC, which to some extent relied on Skandia's model. The analysis was conducted at the angle of the methodological apparatus structure and operationalization. The article is an effect of an analysis of the main foreign literature and also aims at filling of the gap which exists in literature about the NIC concept.

\section{Skandia Navigator model as the foundation of NIC concept development}

The first attempt of measurement of intellectual capital at the national level based on achievements of the Swedish insurance enterprise "Skandia AFS". Within the framework of Skandia an innovative method of reporting the intellectual capital of organisation was worked out. It was a reaction to the incompleteness of traditional, financial reports in respect of information about intangible assets (so-called invisible assets) - main generator of the value of enterprises. The internal report about the state of these invisible assets of Skandia developed in 1985 [Bontis, 2000, p. 45]. This was preceded by the work of the current professor of Lund University, at that time the world's first (1991) director for intellectual capita at Skandia - Leif Edvinsson. In 1993, he developed Skandia's Value Scheme. On its basis Edvinsson with his team constructed Skandia Navigator ${ }^{2}$ model - a tool of management and reporting of

${ }^{1}$ VAIC - A. Public, ICM - Andriessen Stam, IC-dVAL - Bounfour, INTAN - Lopez Nevado Alfaro, [Labra Sanchez 2013, p. 589], NICI - Bontis [Nazari Herremans 2007, p. 600]

${ }^{2}$ The first public addition to the annual financial report basing on Skandia Navigator was published in 1994 - "Visualizing intellectual capital in Skandia", in 1995 officially published two supplements under 
company's intellectual capital. The first practical application of it took form of the appendix to the financial annual report about intellectual capital [Ondari-Okemwa 2011, p. 140]. From that moment, hundreds of companies around the world take the action of implication intellectual capital reporting [Bontis, Serenko, 2013, p. 479], which is an way of announcement to stakeholders about intangible assets and prospects of the development.

Skandia Value Scheme organizes the both kinds of market value of the company factors - material aggregated in financial capital and intangible assets reflecting the intellectual capital. Taking into account intangible capital in the structure of value creation was aimed at filling the information gap on the value generators. Supplementing financial factors by intellectual capital reporting allowed for the visualization of it, the possibility of forming a strategic vision of the development for stakeholders, the basic competences presentation, the properties of knowledge assets and way of knowledge flows within the organization [Bontis, 2000, p. 45]. According to Edvinsson and Malone, the intellectual capital includes experience, organizational technology, relationship with clients and professional skills in order to ensure advantage over Skandia's competitors. Edvinsson expressed intellectual capital as the sum of human capital and structural [Edvinsson, Malone, 1997, pp. 11, 34-37] The first type of capital specifies a combination of knowledge, skills, innovativenes, the ability to meet the tasks by company's employees and culture, philosophy or values of the company. Second capital - structural consists of everything of organizational capability that supports employees productivity, for example: hardware, database, patents, software, organizational structure. Structural capital, unlike human, can be own and thereby traded [Bontis, 2000, p. 5] Figure 1. illustrates Skandia Value Scheme.

FIGURE 1.

\section{Skandia Value Scheme}

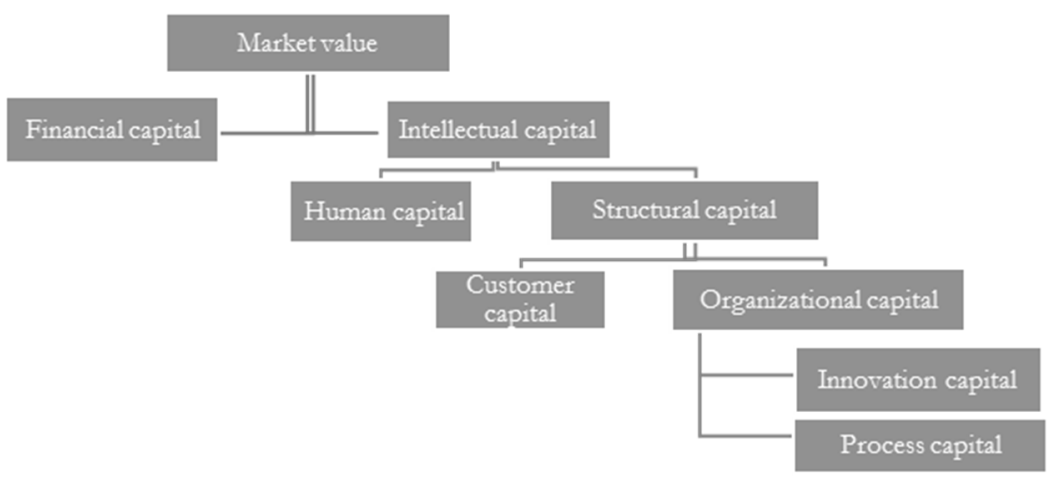

Source: [Bontis, 2000, p. 46].

the title: "Renewal and development intellectual capital" and "Value-creation process: intellectual capital". In 1996 next Skandia studies were made available: "Power of innovation: intellectual capital" and "Customer value" [Bontis, 1998, p. 74] 
In Skandia Value Scheme structural capital is divided into customer capital (relationship with the company's clients) and organizational capital. Organizational capital is broken down into innovation (represents the enablers to innovatte products and proces) and process capital (relates to the procedures and routines of the company's internal process), [Marr, Schiuma, Neely, 2004, p. 556].

In 1994, on the basis of the relationship between elements of the Scheme and its classification, Edvinsson developed Skandia Navigator. This model is a comprehensive reporting tool of company value through the aggregation of the factors that create it on five areas: financial, human, customer, process, renewal and development, which are define like in Skandia Value Scheme [Bontis, 2000, p. 45]. The essence of this solution is explained with using the metaphor of a house whose roof is tangible financial dimension of value creation, created in the past. The material part of the Skandia's market value results from traditional financial statements [Marr, Schuima, Neely, 2004, p. 555]. The function of the external pillars performs prosess capital and customer capital. They surround central part of the house - human capital. Metaphorical walls and the interior compose invisible assets generating value in the present. The foundation of the house in the form of renewal and development capital generates value in the future. The last type of capital is particularly significant from the point of view of Skandia's Navigator value-added compared to the previous ones [Nazari, Herremans, 2007 , p. 600]. The emergence of renewal and development capital balances information shortage of traditional reporting, concerning the possibilities of development and plans of the company. Skandia Navigator approach splits IC - as intanfible assets of comapany - into four categories: human, customer, proces and innovation capital. The visualization of Skandia Navigator presents Figure 2.

FIGURE 2.

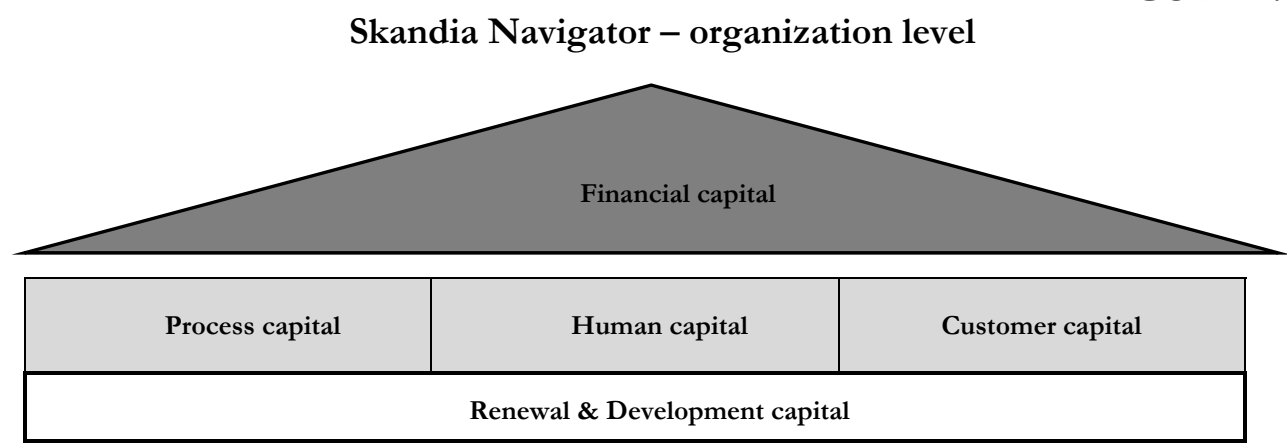

Source: [Opper, 2007, p. 11]

In Scandia Navigator human capital is defined as a sum of skills, competencies, abilities and experiences. Process capital means infrastructure support for human capital including organisational processes, procedures, technologies, sources and information flow system and intellectual property. Customer capital includes the value in the business relations with the environment: customers, suppliers, organizations [Malhotra, 2003, p. 7]. Location of human capital in the center, in the heart of the house is an expression of 
the nature and importance of this kind of capital. Human capital is an activator of activities and constitutes the type of binder between the blocks, because through it comes to interacting with other components [Opper, 2007, p. 11].

The creation Skandia Navigator model is an extremely important moment and achievement in the development of intellectual capital concept. Model's taxonomy has changed the traditional approach to the factors generating the value of the company, offering the extension of the evaluation and measurement the horizon of market value. Information capacity of this tool provided a new quality of reporting, giving the ability to communicate to stakeholders about the organizational and prosess structure, external relations and development prospects. This aspect was emphasised by Edvinsson concluding that the Navigator "reinforces the dynamics of the relationship between basic areas (...) can also get an extensive reporting system that provides more information than the traditional financial statement" [Community Intelligence Labs...]

\section{Transformation of Skandia's models to the national level}

From a macroeconomic perspective the intellectual capital was recognised as the determinant of the wealth of the country only in the 90s of the last century [Labra, Sanchez, 2013, p. 584]. The concept of NIC emerged as a result of the transformation of intellectual capital theory from the company level. The pioneering initiative to expand the scope of the research object was making gradually in Sweden - the cradle of NIC concept.

The need of widening the scale of research on intellectual capital to the national level was determined by many reasons. The first of these was functioning of ISA (Invest in Sweden) and the establishment 1996 year was the year of innovation in Sweden. Another of them was the foundation of Skandia Future Centre by led of Edvinsson on the initiative of the government of Sweden. In Skandia Future Centre work on adapting the model Skandia Navigator to the national level has been months in the making ${ }^{3}$. The effects of it were presented at the First International Meeting on Visualisation and Measuring the IC of Nation in 1998 [Edvinsson, 2004, p. 157].

One of world's first reports on intellectual capital of Sweden [Rembe, 1999] applied an adopted to macroeconomic scale model of the Skandia Navigator [Lin, Edvinsson, 2011, p. 8]. Transformation was a result of the cooperation of the Swedish government with the university ${ }^{4}$ and well as practices. Undoubtedly, the achievements of Skandia initiated progress in the approach to the NIC reporting and exposed the importance of intangible determinants of country development.

Edvinsson defines national intellectual capital as future earnings capabilities. NIC includes knowledge, wisdom, capability, experience what provide competitive advantage and determine future gowth. [Edvinsson L., Lin C. 2011, p. 3]

\footnotetext{
3 One previous NIC report was emerged in 1997 - „Welfare and Security - For future generations” (Jarehad and Stenfelt), Sweden.

${ }^{4}$ L. Edvinsson invited C. Stanfetl of Stockholm University and several fellow students to work on the transformation model Skandia Navigator [Edvinsson, 2004, p. 157].
} 
Transformation of Skandia Value Scheme and Skandia Navigator from the corporate to the nation area was not a difficult task, what was confirmed by the author L. Edvinsson in the article from 2004 - "The Intellectual Capital of Nations" [Edvinsson, 2004, p. 157]. The adaptation consisted of some changes in model's nomenclature. The names of scheme elements have been changed as follows: "market value" was replaced by "the wealth of the country", "financial wealth" in place of "finance capital", in turn "customer capital" was replaced by "relations capital". The other parts remained unchanged. The visualization of Skandia Value Scheme of the nation including the structure of the national intellectual capital is presented in Figure 3 .

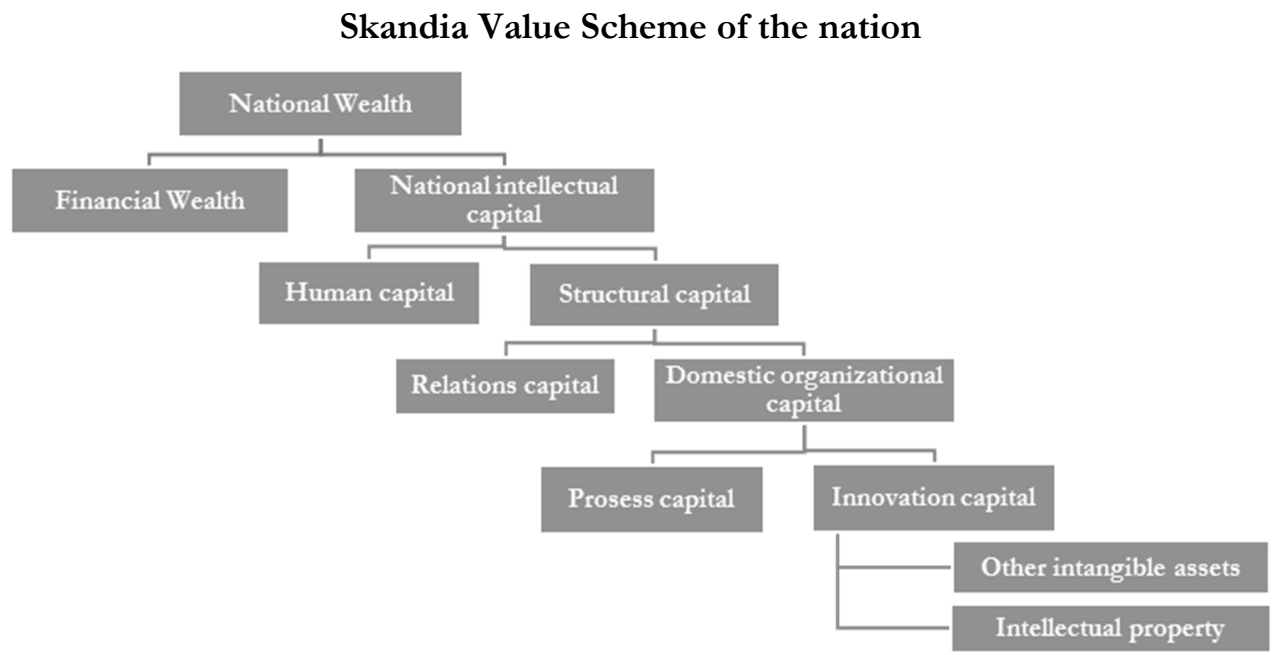

Source: [Edvinsson, 2004, p. 159].

In the Skandia Navigator model, transformed to requirements of the macroeconomic scale, five areas were singled out. Financial wealth, which is the property of the country was created in the past. Human capital is a centre of the house, invariably to the primal version. Human capital is located on one horizontal level with external relations pillar and pillar of the internal capacities and IT. Human capital interacts with the other components of national intellectual capital. The foundation of the house is future potential, including renewal, development and innovation capital. The construction of the scheme Skandia Navigator as a metaphorical home in macroeconomic perspective is shown in Figure 4. 
FIGURE 4.

Skandia Navigator model transformed to the national level

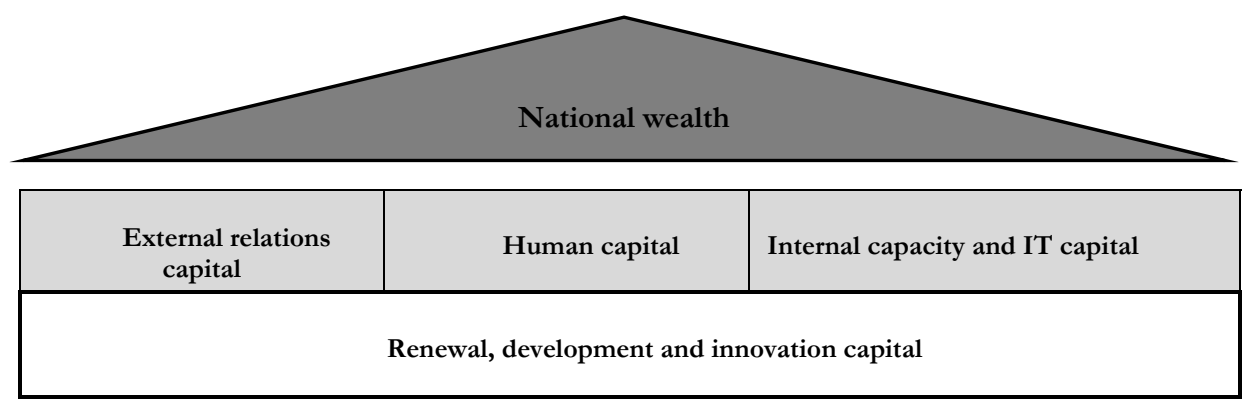

Source: [Edvinsson, 2004, p. 156]

The evaluation of the national wealth from this model point of view enables the comprehensive diagnosis of strengths and weaknesses of the examined economy. The effects of this method do not have fragmented nature/features in contrast to the standard measuring methods of the development possibilities. Skandia Navigator allows to identify value generators not only in various perspectives of wealth creation e.g. financial capital, human capital, renewal, development capital, but also with reference to the past, the present and the future time.

\section{Diagnosis of the level of NIC - models based on Skandia methodology}

Sweden is a pioneer country in the development of research on the intellectual capital concept at the macroeconomic level. A. Rembe with ISA issued one of the world's first publication as the report about the state of intellectual capital in Sweden, entitled "Welfare and Security" in 1999. The applied model of Swedish NIC is based on the concept of intellectual capital, which consists of four blocks: human, market, proces and renewal \& development capital [Pomeda, Moreno, Rivera, Martil 2002, p. 8].

A second study of national intellectual capital was carried out in Israel by E. Pasher. The results of research published in 1999 entitled " A look to the future: The hidden values of the Desert". The methodology of Israel report used the intellectual capital classification from Skandia model, separating IC on human capital, market capital, processes capital, and renewal \& development capital. Pasher did not only demonstrate the macroeconomic dimension of the value creation, but also expressed conclusions which showed that the advantages of small Israeli economy stuck in human resources, technical resources and modern infrastructure [Opper, 2007, p. 6]. Later, two other versions of NIC report of Israel were created. The first was prepared by E. Pasher and S. Schachar in 2004 and the other one was developed by E. Opper in 2007. The conceptual model has not changed in both of them.

Next publications using Skadnia achievements about NIC were created by N. Bontis in 2002 nad 2004, showing effects of examinations of Marseille economy and 10 Arab 
countries. In these works, besides the financial capital, the national intellectual capital was divided into four components: human, market, processes, renewal capital [Bontis, 2000; Bontis, 2004]. Bontis applied financial indicators and quality methods concerning characteristics of the immaterial wealth for the measurement of the national intellectual capital [Edvinsson, Lin, 2008, p. 528]. Wider than in previous researches, the range of applied methods/indicators was the result of the author's assumptions, that intellectual capital on the macroeconomic scale should be assessed from various perspectives, for instatnce: from health, poverty or gender equality point of view [Edvinsson, Lin, 2008, p. 529]. Every indicator stayed standardized from 1 to 10 scale in one of four areas [Labra, Sanchez, 2013, p. 589].

The theoretical measurement model developed by Malhotra in 2003 relating to national knowledge assets, based also on the structure of Skandia methodology. The author followed the OECD definition which accepted that intellectual capital is a subset of intangible knowledge assets of the country. Malhotra has identified four components NIC: human, processes, market and renewal \& development capital. The elements of NIC are in the same relationship to each other as in the Skandia Value Scheme [Malhotra, 2003, pp. 3, 24].

Skandia Navigator constituted a pillar of the adopted assessment method of Finland in 2005. Stahle and Pasher decided that NIC is made up of segments such as: human capital, market capital, processes capital, renewal \& development capital. The measurement was conducted making use of financial variables, national measures and indicators of Finland industries [Edvinsson, Lin, 2011, p. 12].

D. Węziak built conceptual model of the national intellectual capital dividing it into the human capital, structural capital, relations capital and renewal \& development capital. The author made the diagnosis of NIC level in twenty four countries of the European Union [Węziak, 2007]. She got the overall results in the form of the intellectual capital index obtained by adding individual indicators up with the subjectively established weight [Labra, Sanchez, 2013, p. 589].

In their works from 2008 (diagnosis of NIC in five Nordic countries) and 2011 from (diagnosis of NIC in 40 countries) Edvinsson and Lin adopted Edvinsson's model and supported it by Bontis's construction (2004), which was established as a result of modification of Skandia Navigator too [Seleim Bontis 2013, p. 132]. NIC was formulated as the sum of human capital, market capital, process capital and renewal capital. However, in contrast to Bontis's method, the final result of the calculation took into account the impact of the logarithm of GDP per capita in purchasing power of each country. Operationalisation was made using two types of indicators - absolute values and the qualitative ones measured by the 1-10 point scale. [Edvinsson Lin 2008, pp. 530-531]

Also in Poland an attempt of assessment the level of NIC was adopted. In 2008, a team under the leadership of M. Boni published Report on Intellectual Capital of Poland. To identify the intellectual capital of Poland, they borrowed taxonomy based on four components: human capital, structural capital, social capital and relations capital. In the report, Skandia Navigator was not mentioned as the initial inspiration, however, the definition of NIC in Polish methodology came from Bontis and Malhotra's thesis (they built conceptual models of the Skandia Navigator), [ZDSP 2008, p. 21]. The ingredients 
of NIC clearly different from earlier examples, mainly by the occurrence of the social capital. Social capital according to Boni's methodology means "society potential in the form of the standards of conduct, trust, commitment, which constitute the support of cooperation and exchange of knowledge" [ZDSP, 2008, p. 6]. Structural capital could be treated analogously to process capital due to the similarity of definitions.

In Phusavat's, Comepa's, Sitko - Lutek's, Ooi's diagnosis of the intellectual capital of Thailand, the authors assumed that human capital, market (customer) capital, process (information) capital and innovation capital form the NIC model. The differing accent of NIC assessment at this approach was a division of organizational capital into the capital of innovation and process/information [Phusanvat al., 2012, pp. 869, 875-876]. It should also be emphasized that the structure of the organizational capital in Thailand model derives from Skandia Value Sheme. The adopted in the article definitions of these components show that the innovation capital should be explicitly interpreted with a term of the renewal \& development capital.

Presented examples of conceptual NIC models are not exhausting all their spectrum 5 . They belong to the most common group, the so-called academic models ${ }^{6}$. Analyzed conceptual models of NIC divide intellectual capital into four components. In each of the presented conceptual models based on Skandia Navigator human capital occurs, which is a combination of knowledge, skills, innovation and the ability of the individuals, including the values, culture and philosophy of the nation. Human capital includes wisdom, experience, intuition, the ability of individuals to create value and achieve the objectives [Malhotra, 2003]. According to Bontis, in terms of macroeconomic perspective human capital is the level of citizens' competence used in the implementation of national tasks [Bontis, 2004]. Human capital is the most homogeneous component of NIC with fundamental importance. It is a kind of material not only for the creation of other NIC elements, but also the basis for obtaining benefits from them [Michalczuk, 2013, p. 105]. Other components adopt different names but very often pertain to the same area of intangible generators of value.

To sum up, the authors most often create their methodology on the basis of the concept consisting of such components as human capital, market capital, processes capital and renewal \& development capital.

\footnotetext{
${ }^{5}$ The subject of the authors's analysis was 13 research papers and on their base were identified conceptual approaches to NIC diagnosis.

${ }^{6}$ Two groups of models were distinguished in literature (models drawn up by research workers "academic models" and models created by international organizations - "international organization models"), which are used for the evaluation of NIC. This classification arose as a result of findings among: [HarvasOlivier, Dalmau-Porta, 2006; Alfaro et al., 2011; Lopez et al., 2011; Labra, Sanchez, 2013, p. 588]. However, the research sample does not mean, that methods of NIC assessment designed by international organizations make use of Skandia achievements. For example World Bank methodology - KAM from 2006 year bases on Skandia Navigator model [Navarro, Pena, Ruiz, 2010, p. 514].
} 


\section{Operationalization of selected conceptual models based on of Skandia methodology}

The diagnosis of NIC requires a system of variables that allows to measure the invisible wealth of the country and to manage it. Concept models based on the Skandia Navigator are a group of relatively clear methods with a substantial degree of freedom of choice by selecting NIC indicators. Its versatility and ease of adaptation allows a big selection of measurable and immeasurable characteristics to reflect the value of the individual components. Adopted in the analyzed work classifications of national intellectual capital enabled the operationalization of models by measuring these elements. To that measurement indicators were used characterizing these segments of a different nature (financial indicators, qualitative variables, descriptions). The examples of variables expressing the value of the NIC components are presented in Table 1.

The practical application of a modificated version of Skandia Navigator in Rembe's report to the assessment method of NIC for Sweden in 1999 was undoubtedly a breakthrough moment. The author used financial and descriptive indicators for the innovative measurement of the intellectual capital on a national scale [Edvinsson Lin 2008, p 528]. The results of Swedish NIC reporting took the form of consideration regarding the growth determinants foreign investment perspective in Sweden. The factors of Swedish attractiveness were located in the category of national intellectual capital. This publication also includes a proposal for a plan of the further development of Swedish intellectual capital. [Pomeda, Moreno, Rivera, Martil 2002, p. 8]

The conceptual models created by Bontis, Edvinsson and Lin are among the group of methods using the NIC benchmarking. NIC benchmarking relies on measuring the NIC level of chosen objects and comparing their results. [Januskaite, Uziene 2015, p. 163] The work of Phusavat and others also made the ranking Thailand in regard to the four neighboring economies.

The most complex measuring tool (not only for the amount of indicators, but mainly due to the multi-level construction) is Boni's model evaluating Polish NIC with the division of generations. The decomposition of national intellectual capital on generational groups (children and young people, students, adults, seniors) required building the models for each of them. Generations were characterized as appropriate and differing from each other subcategories of the Polish intellectual capital. It caused the necessity for an examination of the relationship between them to get a comprehensive and final result. The methodology used in the Polish report is an innovative tool on a global scale. The advancement of it increases the rank of the conceptual model and causes dissonance in relation to the studies research papers or others existing groups of NIC measurement methods. 
TABLE 1.

A selected characteristics(quantitative and qualitative indicators, descriptions) of the components of NIC models

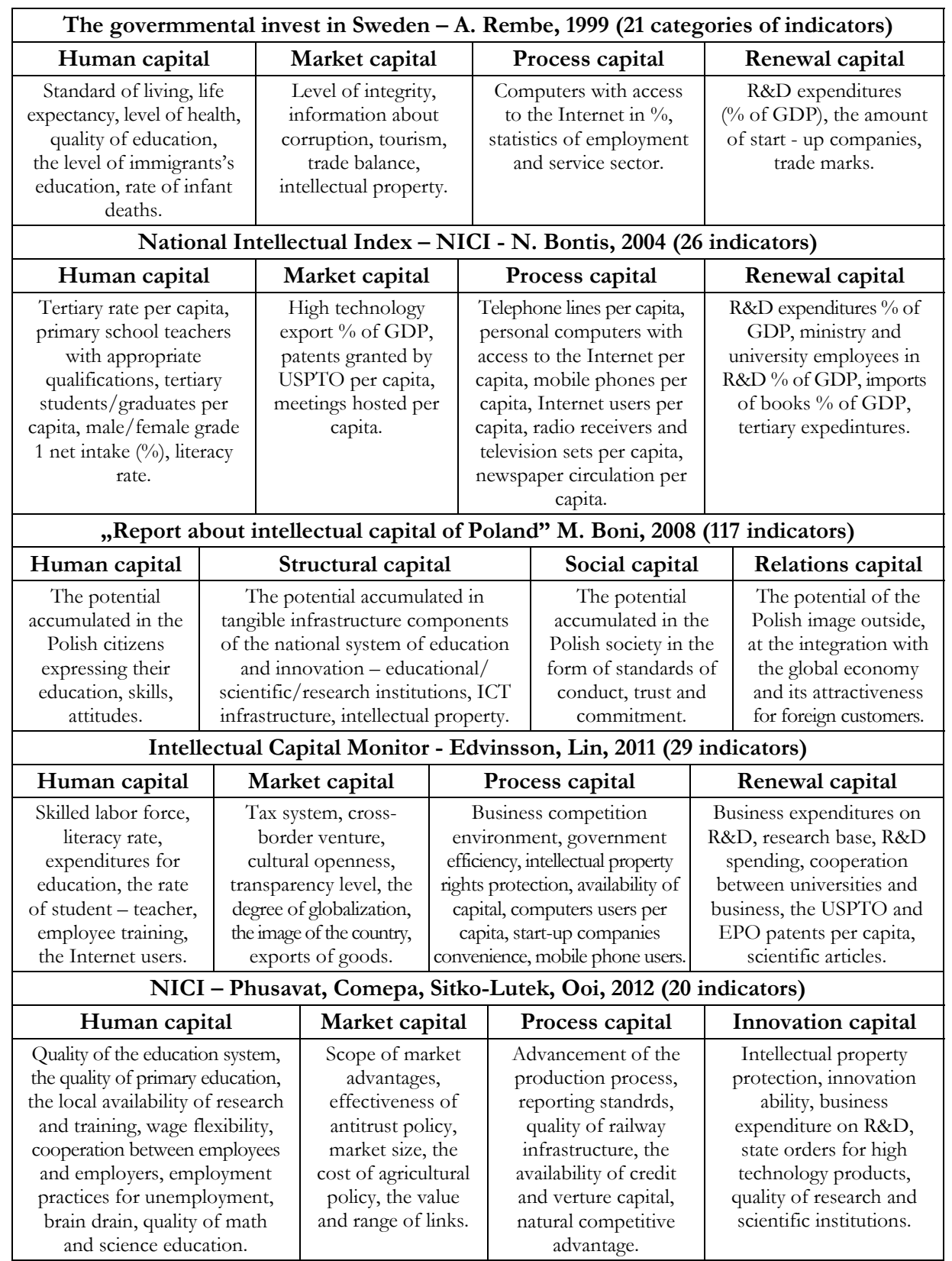

Source: authors's own work base on: [Bontis, 2004; Edvinsson, Lin, 2011; Phusavat at al., 2012; Rembe, 1999; Węziak-Białowolska, 2010; ZDSPRM, 2010]. 


\section{Conclusions}

The concept of national intellectual capital was established on the considerations about it in organization scale. The microeconomic perspective is the main subject of discussion on intellectual capital. The development of the knowledge-based economy caused that began to recognize also the importance of intangible assets in relation to the national economy. It proved that not only financial capital determines wealth of the country. The intellectual capital becomes increasingly a generator of value. L. Edvinson's innovative solutions (Skandia Navigator and Skandia Value Sheme) have been the pillars of many attempts of NIC assessment. As a result, Edvinsson should be regarded as the pioneer of the concept in national terms. Currently, a constant growth of the amount of new models of the NIC assessment is observed. However, amongst the broad spectrum of methods 7 , considerable part of them are based on Edvinsson's achievements. Accordingly, Skandia's methodology does not lose popular over time. Models found on Skandia Navigator are relatively simple tools mesuring NIC. This group of methods are easy to adapt and modify, what allow to adjust of the conceptualzation and methodology to the author's intentions and specific object of analysis. On the other hand, the ease of adaptation to identified conditions and applications may disclose the imperfections of the Skandia's methods. The main one of them is static dimension of the obtained results of measurement, which is a consequence of the reporting orientation of Skandia [Bontis, 2000, p. 48].

Analyzed conceptual models consists of four components in this research paper. In each of them human capital appeared. Assuming the identity of capital development and renewal capital that many authors used interchangeably or replacement at the same level, it can state that developmet capital was the second, next to market and proces capital, most common distincted element in NIC models. There are four basic components of intellectual capital: human, market, processes and renewal \& development capital in the ten of thirteen analized models. It necessary to note, that the convergence of the names of NIC components is inadequate to using the same definitions and indicators describing elements of NIC. Additionally, it shall be pointed out that they are characterized by the different degree of complexity. As a consequence, there is a lack of unanimity in defining, categorizing and measuring national intellectual capital. This diversity is reflected in NIC reporting limits the ability to compare NIC reports of countries, which carried out assessment of it. It is not an isolated problem. Similar observations are identified by referring to intellectual capital of organization. According to A. Brooking, P. Board and S. Jones difficulty in clarifying the concept of intellectual capital and its categorization is meaning capacity and some kind of elusiveness of it. [Brooking, Board, Jones, 1998, p. 115-125]. This fact does not diminish the importance of the intellectual capital concept, which is being tried to organize, classify the dispersed and often unaware intangible generators of the country wealth.

\footnotetext{
7 Next to the Skandia Navigator, other comprehensive measurement systems: Intangible Assets Monitor, Balanced Scorecard, IC-index, Technology Broker Model.
} 


\section{The authors' participation in the preparation of the article}

Julita Fiedorczuk, M.A. - development of the research concept, carrying out the research, developing results, data collection and literature analysis, preparation of the introductory section (theoretical), formulation of the summary $-50 \%$

Grażyna Michalczuk, Ph.D., Professor of the University of Białystok - development of the research concept, carrying out the research, developing results, data collection and literature analysis, preparation of the introductory section (theoretical), formulation of the summary $-50 \%$

\section{References}

Bontis N., 1998, Intellectual Capital: An Exploratory Study that Develops Measures and Models, "Management Decision, Vol. 36, Issue 2, DOI: 10.1108/00251749810204142.

Bontis N., 2000, Assessing Knowledge Assets: A review of the Models Used to Measure Intellectual Capital, "International Journal of Management Reviews", Vol. 3, Issue 1, 10.1111/1468-2370.00053.

Bontis N., Serenko A., 2013, Investing the Current State and Impact of the Intellectual Capital Academic Discipline, "Journal of Intellectual Capital", Vol. 14, Issue 4, DOI: 10.1108/ JIC-11-2012-0099.

Brooking A., Board P., Jones S., 1998, The Predictive Potential of Intellectual Capital, "International Journal of Technology Management", Vol. 16.

Community Intelligence Labs: „L eading Lights” Interview with Leif Edvinsson, http:/ / www.co-i-l.com/ coil/knowledge-garden/ic/edvinsson.shtml (accessed: 16.06.2016).

Edvinsson L., 2004, The Intellectual Capital of Nations, Handbook on Knowledge Managemnet 1: Knoowledge Matters, Spiners Science \& Business media B. V.

Edvinsson L., Lin C. 2008, National Intellectual Capital: A Comparison of the Nordic Countries, "Journal of Intellectual Capital”, Vol. 9, Issue 4, DOI: 10.1108/146919 30810913140.

Edvinsson L., Lin C., 2011, National Intellectual Capital: A Comparison of 40 Countries, Springer Science+BusinessMedia, DOI 10.1007/978-1-4419-7377-1_2.

Edvinsson L., Malone M. S., 1997, Intellectual Capital: Realizing Your Company's True $V$ alue by Finding its Hidden Brainpower, HarperBusiness, New York.

Januskaite V., Uziene L., 2015, Intellectual Capital Measurements and National Strategy Development: Explaining the Gap, Procedia Social and behavioral Sciences 213, DOI: 10.1060/j.sbspro.2015.11.420.

Labra R., Sanchez M. P. 2013, National Intellectual Capital Assessment Models: A Literature Review, "Journal of Intellectual Capital", Volume 14, Issue 4, DOI: 10.1108/JIC11-2012-0100.

Malhotra Y., 2003, Measuring Knowledge Assets of a Nation: Knowledge System for Development, Knowledge Management Measurement: State of Reaserch 2003-2004, New York, http:/ / km.brint.com/KnowledgeManagementMeasurementResearch.pdf (accesed: 16.06.2016). 
Marr B., Schuima G., Neely A., 2004, Intellectual Capital, Definig Key Performance Indicators for Organizational Knowledge Assets, "Journal of Intellectual Capital”, Vol. 10, Issue 5, DOI: $10.1108 / 14637150410559225$.

Michalczuk G., 2013, Zasoby niematerialne jako caynnik wartości przedsięiorstwa. Luka informacyjna sprawozdawczości finansowej, Wydawnictwo Uniwersytetu w Białymstoku, Białystok.

Navarro J. L. A., Pena D. N., Ruiz V. R. L., 2010, A Model to Measure Intellectual Capital Efficiency at National Level: Comparison, Results and Relationships, Proceeding of the European Conference on Intellectual Capital, Business Source Complete.

Nazari J. A., Herremans I. M. 2007, Extended V AIC Model: Measuring Intellectual Capital Components, "Journal of Intellectual Capital", Vol. 8, Issue 4, DOI: 10.1108/ 14691930710830774.

Ondari-Okemwa E., 2011, The Strategic Importance of Identifying Knowledge-Based and Intangible Assets for Generating Value, Competitiveness and Innovation in Sub-Sabaran Africa, "SA Jnl Libs \& Info Sci", Numer 77(1), http://sajlis.journals.ac.za/ pub/article/viewFile/56/48 (accessed: 11.06.2016).

Opper E., 2007, The Intellectual Capital of The State of Israel, http://economy.gov.il/ $\mathrm{RnD} /$ Documents/intellectualcapital.pdf (accessed: 12.06.2016).

Phusavat K., Comepa N., Sitko-Lutek A., Ooi K-B., 2012, Intellectual Capital: Implementation for Industrial Competitiveness, "Industrial Management \& Data Systems", Vol. 112, Issue 6.

Pomeda J. R., Moreno C. M., Rivera C. M., Mártil L. V., 2002, Towards an Intellectual Capital Report of Madrid: New Insights and Developments, opracowanie prezentowane na: The Transparent Enterprise. The Value of Intangible, Madryt, http://citeseerx.ist.psu.edu/viewdoc/download?doi=10.1.1.122.5377\&rep=rep 1\&type $=\operatorname{pdf}($ accessed: 09.06.2016).

Raport o Kapitale Intelektualnym Polski, 2010, Zespół Doradców Strategicznych Prezesa Rady Ministrów, http://kramarz.pl/Raport_2008_Kapital_Intelektualny_Polski.pdf (accessed: 23.03.2016).

Rembe A., 1999, The Govermmental Invest in Sweden Agency - IS A, Report 1999, Halls Offset Ab, Stockholm.

Roslender R., Fincham R., 2004, Intellectual Capital Accounting in the UK. A Field Study Perspective, "Journal of Intellectual Capital", Vol. 17, Issue 2, DOI: 10.1108/ 09513570410532429.

Seleim A., Bontis N., 2013, National Intellectual Capital and Economic Performance: Empirical Evidence from Developing Countries, "Knowledge and Process Management", Vol. 20, Issue 3, DOI: 10.1002/kpm.1412.

Węziak D., 2007, Measurement of National Intellectual Capital: Application to EU Countries, "IRISS Working Paper Series", No. 13, Insed, Luxemburg, http://iriss.ceps.lu/ documents/irisswp81.pdf (accessed: 30.03.2016).

Węziak-Białowolska D., 2010, Model keapitału intelektualnego regionu. Koncepcja pomiaru i jej zastosowanie, Wydawnictwo SHG, Warszawa. 